\title{
Development and validation of UV-spectrophotometric methods for quantitative estimation of Prothionamide in pure and pharmaceutical dosage forms
}

\author{
*Sujit Kumar Debnath, S. Saisivam, Dillip Kumar Dash and Monalisha Debnath \\ N. R. Vekaria Institute of Pharmacy, Junagadh, Gujarat-362001, India
}

\begin{abstract}
UV Spectrophotometric method was developed and validated for the quantitative determination of Prothionamide in bulk drug and in pharmaceutical formulations. Prothionamide shows the maximum absorbance at $288 \mathrm{~nm}$ in phosphate buffer (pH 7.4). Prothionamide follows Beer's law in the concentration range of $4-20 \mu \mathrm{g} / \mathrm{ml}\left(r^{2}=0.999\right)$. The detection limit (DL) and quantitation limit $(\mathrm{QL})$ were 0.406 and $1.229 \mu \mathrm{g} / \mathrm{ml}$ respectively. Accuracy and precision were found to be satisfactory. The developed methods were validated according to $\mathrm{ICH}$ guidelines. All the validation parameters were found to be satisfactory accordance with the standard values. Therefore, the proposed method can be used for routine practice for the determination of Prothionamide in assay of bulk drug and pharmaceutical formulations.
\end{abstract}

Key Words: Prothionamide, validation, UV-Spectrophometry, antitubercular drug, content determination.

\section{INTRODUCTION}

Prothionamide is chemically 2-Propylpyridine-4carbothionamide with molecular weight of 180.3. It has been proposed as second line Tuberculostatics as it has activity against Mycobacterial species including M. lepae and M. avium by inhibiting peptide synthesis (Bijev and Georgieva, 2010). The absorption of Prothionamide following oral administration appears to be rapid and completely absorbed from gut wall. First pass metabolism was absent with an elimination of half-life $2 \mathrm{hr}$ (Venkatesan, 1989). UV Spectroscopy method is the mostly interesting instrumental analytical methods that are widely used in for the assay of pharmaceutical products, because for its simple, easy, less time consuming and an economical method (Nijhu et al., 2011). Prothionamide is official in IP (Indian Pharmacopoeia, 2010, JP (Japan Pharmacopoeia, 2011). Previous literature survey suggested the existence of HPLC method using NS-4000 (Lee et al., 2012), Eurobond RP18 (IP, 2007), Kromasil 100 C4 column (Bartels and Bartels, 1998). Kumar and Sreeramulu (2011) reported stability indicating RP-HPLC with Shimazdu LC-20AT series. Thin layer chromatography was reported by GPHF-Minilab (2010). No UV spectrophotometric method is available for the estimation of Prothionamide formulation at $\mathrm{pH}$ of 7.4. So, it was felt necessary to develop a UV spectrophotometric method where no complexation agent, and no baleful chemicals, no extraction, derivatization, or evaporation step, are involved.

\section{MATERIALS AND METHODS}

\section{Chemicals and Reagents}

Prothionamide was procured from Yarrow Chem products, Mumbai. Protomid (Prothionamide tablets IP 250mg, batch no: APB304A Macleods Pharmaceuticals Ltd.) was

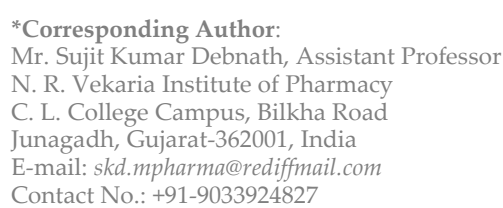

purchased from local market. All other reagents used in this study were of AR grade. Distilled water was used for making the solution.

\section{Instrumentation}

The UV method was performed on Shimadzu (Model: UV-1800) double beam spectrophotometer with UV-probe software version 2.31. The absorption spectra of all the solution were carried out in the range of $200-400 \mathrm{~nm}$.

Preparation of stock solutions and test solutions \& wavelength of maximum absorbance $\left(\lambda_{\max }\right)$ determination Stock solution $(1000 \mu \mathrm{g} / \mathrm{ml})$ of Prothionamide was prepared in $\mathrm{pH} 7.4$ phosphate buffer and sonicated for 20 min. The absorption maximum was determined using 10 $\mu \mathrm{g} / \mathrm{ml}$ solution by scanning at 200 to $400 \mathrm{~nm}$ in UVDouble beam spectrophotometer (table 1).

Preparation of working standard solution for calibration curve

The standard solution $(1000 \mu \mathrm{g} / \mathrm{ml})$ was further diluted with $\mathrm{pH} 7.4$ phosphate. The diluted solution were vortexed and then used for further analysis. The calibration curve was plotted between concentrations and absorbances (table 2).

\section{Method Validation}

The methods were validated according to ICH guidelines of Q2B (2005) in terms of linearity, sensitivity, precision and accuracy for each analyte.

\section{Linearity}

Five point linear curve was prepared by plotting concentration $(\mu \mathrm{g} / \mathrm{ml})$ vs. absorbance and correlation co-efficient was calculated (figure $\mathbf{1}$ ).

Limit of detection (LOD) and limit of quantification (LOQ)

The limit of detection (LOD) is defined as is the lowest concentration of a substance that an analvtical process can reliably distinguished from the absence of that substance. The limit of quantification (LOQ) is defined as the lowest concentration of the standard curve that can be measured 
Table 1: Summary of the UV method validation.

\begin{tabular}{rl|}
\hline Parameters & UV-method \\
Working $\lambda_{\max }$ & $288 \mathrm{~nm}$ \\
Beer's law limit & $4-20 \mu \mathrm{g} / \mathrm{ml}$ \\
& $\mathrm{y}=0.049 \mathrm{x}+0.004$ (without \\
& zero interpretation) \\
Regression equation & $\mathrm{y}=0.050 \mathrm{x}$ (with zero \\
& interpretation) \\
Regression coefficient (r) & 0.999 \\
SD of slope & 0.0016 \\
SD of intercept & 0.0059 \\
LOD & 0.397 \\
LOQ & 1.204 \\
\hline
\end{tabular}

Table 2: Standard curve of Prothionamide at pH 7.4.

\begin{tabular}{cc}
\hline Concentration $(\mu \mathrm{g} / \mathrm{ml})$ & Absorbance \\
\hline 4 & 0.207 \\
8 & 0.399 \\
12 & 0.599 \\
16 & 0.810 \\
20 & 0.999 \\
\hline
\end{tabular}

with acceptable accuracy, precision and variability $(\mathrm{ICH}$ guideline Q2B, 2005) (table 1). The LOD and LOQ were calculated as:

$$
\begin{aligned}
& L O D=3.3 \times \frac{S D}{S} \\
& L O Q=10 \times \frac{S D}{S}
\end{aligned}
$$

Where, $\mathrm{S}=$ slope of the linearity curve (0.049), $\mathrm{SD}=$ standard deviation of $y$-intercept

\section{Analysis of tablet formulation}

20 marketed tablets of Prothionamide (Protomid, Macleods Pharmaceuticals Ltd.) were weighed and ground to fine powder; amount equal to $10 \mathrm{mg}$ of Prothionamide was taken in $100 \mathrm{ml}$ of volumetric flask and the volume was made up to mark with $\mathrm{pH} 7.4$ phosphate buffer. The flask was sonicated further for 20 min to solubilize the drug present in tablet powder. After sonication, filtration was done through Whatman filter paper No. 41. Filtrate was collected and further diluted with $\mathrm{pH} 7.4$ phosphate buffer to get the final concentrations of drug in the working range. The absorbance of final diluted solution was observed at $288 \mathrm{~nm}$ (table 3).

\section{Accuracy}

Accuracy is the percent of recovered amount by assay

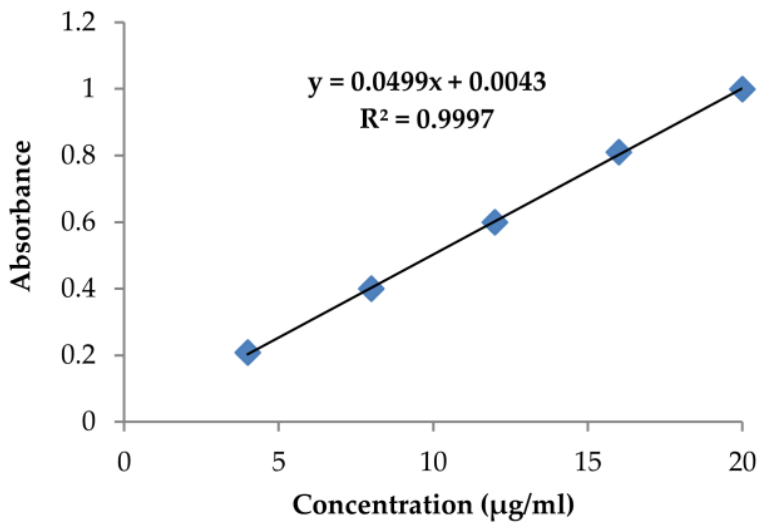

Figure 1: Calibration curve of Prothionamide at pH 7.4.

from a known added amount. For the measurement of accuracy data, nine determinations over three concentration levels (Kavathia and Misra, 2013) were carried out as lower, intermediate and higher concentration from stock solutions and analyzed. The accuracy of the proposed methods was assessed by recovery studies at three different levels i.e., $80 \%, 100 \%$ and $120 \%$ (Jain et al., 2013). Result of recovery studies are reported in table 4.

\section{Precision}

Repeatability was calculated by taking different levels of concentrations, prepared from pure drug stock solution and analyzed. Intermediate precision was calculated by taking the variations of inter-day and intra-day response. Respective concentrations from stock solution in triplicates were prepared three different times in a day and studied for intraday $(n=9)$ and inter-day variation $(n=15)$. The relative standard deviation (\% RSD) of the estimated concentrations from the regression equation was taken as precision (table 5).

\section{RESULTS AND DISCUSSION}

UV-Spectrophotometric method was developed for Prothionamide which can be conveniently employed for routine analysis in pharmaceutical dosage forms and will eliminate unnecessary tedious sample preparations. The standard error, standard deviation, and coefficient of variance were obtained for Prothionamide was satisfactorily low. Prothionamide shows $\lambda_{\max }$ at $288 \mathrm{~nm}$. 5 Point calibration curve data was constructed in the range of 4 to $20 \mu \mathrm{g} / \mathrm{ml}$, where the Beer's law was obeyed. The correlation co-efficient was found 0.999 , which is within the limit $\left(\mathrm{r}^{2}>0.990\right)$. The limit of detection (LOD) and limit of quantification (LOQ) for Prothionamide is found to be

\begin{tabular}{|c|c|c|c|c|c|c|}
\hline $\begin{array}{l}\text { Label claim } \\
\text { (mg/tab) }\end{array}$ & $\begin{array}{l}\text { Conc. prepared } \\
(\mu \mathrm{g} / \mathrm{ml})\end{array}$ & $\begin{array}{l}\text { Conc. recovered } \\
(\mu \mathrm{g} / \mathrm{ml})\end{array}$ & $\begin{array}{l}\text { Amount found } \\
(\mathrm{mg} / \mathrm{tab})\end{array}$ & $\begin{array}{c}\% \\
\text { Label claim }\end{array}$ & $\begin{array}{c}\text { Mean } \pm \text { SD } \\
(n=3)\end{array}$ & $\begin{array}{c}\% \\
\text { RSD }\end{array}$ \\
\hline \multirow{9}{*}{250} & \multirow{3}{*}{10} & 9.82 & 245.5 & 98.2 & \multirow{3}{*}{$98.40 \pm 0.91$} & \multirow{3}{*}{0.925} \\
\hline & & 9.74 & 243.5 & 97.4 & & \\
\hline & & 9.96 & 249.0 & 99.6 & & \\
\hline & \multirow{3}{*}{15} & 14.82 & 247.0 & 98.8 & \multirow{3}{*}{$99.80 \pm 1.56$} & \multirow{3}{*}{1.563} \\
\hline & & 15.3 & 255.0 & 102.0 & & \\
\hline & & 14.78 & 246.5 & 98.6 & & \\
\hline & \multirow{3}{*}{20} & 19.64 & 245.5 & 98.2 & \multirow{3}{*}{$98.87 \pm 0.62$} & \multirow{3}{*}{0.627} \\
\hline & & 19.74 & 246.75 & 98.7 & & \\
\hline & & 19.94 & 249.25 & 99.7 & & \\
\hline
\end{tabular}

Table 3: Estimation of Prothionamide in tablet formulations.

$\mathrm{SD}=$ Standard deviation, $\mathrm{RSD}=$ Relative standard deviation, $\mathrm{N}=$ Average determination . 
Table 4: Recovery studies on marketed formulations.

\begin{tabular}{|c|c|c|c|c|c|c|c|c|c|}
\hline $\begin{array}{l}\text { Conc. } \\
\text { level }\end{array}$ & $\begin{array}{c}\text { Sample } \\
\text { no. }\end{array}$ & Drug & Formulation & $\begin{array}{l}\text { Amount added } \\
(\mu \mathrm{g} / \mathrm{ml})\end{array}$ & Abs. & $\begin{array}{l}\text { Amount } \\
\text { recovered }\end{array}$ & $\%$ recovery & $\begin{array}{c}\text { Mean \% recovered } \\
\pm S D(N=3)\end{array}$ & $\begin{array}{c}\% \\
\text { RSD }\end{array}$ \\
\hline $80 \%$ & $\begin{array}{l}1 \\
2 \\
3\end{array}$ & & $\begin{array}{l}10 \mathrm{ml} \text { of } \\
8 \mu \mathrm{g} / \mathrm{ml}\end{array}$ & 8.90 & $\begin{array}{l}0.437 \\
0.441 \\
0.439\end{array}$ & $\begin{array}{l}8.74 \\
8.82 \\
8.78\end{array}$ & $\begin{array}{c}97.11 \\
98.0 \\
97.55\end{array}$ & $97.55 \pm 0.36$ & 0.39 \\
\hline $100 \%$ & $\begin{array}{l}1 \\
2 \\
3\end{array}$ & $\begin{array}{c}10 \mathrm{ml} \text { of } \\
10 \mu \mathrm{g} / \mathrm{ml}\end{array}$ & $\begin{array}{l}11 \mathrm{ml} \text { of } \\
10 \mu \mathrm{g} / \mathrm{ml}\end{array}$ & 10 & $\begin{array}{l}0.488 \\
0.490 \\
0.492\end{array}$ & $\begin{array}{l}9.76 \\
9.80 \\
9.84\end{array}$ & $\begin{array}{c}97.6 \\
98.0 \\
98.40\end{array}$ & $98.00 \pm 0.33$ & 0.34 \\
\hline $120 \%$ & $\begin{array}{l}1 \\
2 \\
3\end{array}$ & & $\begin{array}{l}12 \mathrm{ml} \text { of } \\
12 \mu \mathrm{g} / \mathrm{ml}\end{array}$ & 11 & $\begin{array}{l}0.536 \\
0.547 \\
0.544\end{array}$ & $\begin{array}{l}10.72 \\
10.94 \\
10.88\end{array}$ & $\begin{array}{l}97.46 \\
99.45 \\
98.90\end{array}$ & $98.60 \pm 0.839$ & 0.85 \\
\hline
\end{tabular}

Table 5: Results of validation (Mean \pm SD).

\begin{tabular}{|c|c|c|c|c|c|c|c|c|}
\hline \multirow{3}{*}{$\begin{array}{l}\text { Conc. } \\
(\mu \mathrm{g} / \mathrm{ml})\end{array}$} & \multicolumn{6}{|c|}{ Intra Day } & \multirow{2}{*}{\multicolumn{2}{|c|}{ Inter Day }} \\
\hline & \multicolumn{2}{|c|}{ DAY-1 } & \multicolumn{2}{|c|}{ DAY-2 } & \multicolumn{2}{|c|}{ DAY-3 } & & \\
\hline & $\begin{array}{c}\text { Repeatability } \pm \\
\text { SD }(N=9)\end{array}$ & $\%$ RSD & $\begin{array}{c}\text { Repeatability } \pm \\
\text { SD }(N=3)\end{array}$ & $\%$ RSD & $\begin{array}{c}\text { Repeatability } \pm \\
\text { SD }(N=3)\end{array}$ & $\%$ RSD & $\begin{array}{c}\text { Repeatability } \\
\pm S D(N=15)\end{array}$ & $\%$ RSD \\
\hline 5 & $0.2464 \pm 0.002$ & 0.8130 & $0.2550 \pm 0.0016$ & 0.6275 & $0.255 \pm 0.0008$ & 0.3137 & $0.2497 \pm 0.0047$ & 1.8823 \\
\hline 10 & $0.4858 \pm 0.0059$ & 1.2145 & $0.4887 \pm 0.0056$ & 1.1459 & $0.4977 \pm 0.0052$ & 1.0448 & $0.4887 \pm 0.0073$ & 1.4938 \\
\hline 15 & $0.7474 \pm 0.0081$ & 1.0838 & $0.7533 \pm 0.0082$ & 1.0885 & $0.7453 \pm 0.0095$ & 1.2747 & $0.7482 \pm 0.0088$ & 1.1762 \\
\hline
\end{tabular}

$0.397 \mu \mathrm{g} / \mathrm{ml}$ and 1.204 respectively, indicating that the proposed UV method is highly sensitive. Assay value of Prothionamide in tablet formulations ranged from $98.40 \pm$ 0.91 to $99.80 \pm 1.56$ with relative standard deviation not more than $1.56 \%$. Assay values of formulation were same as label claim; this indicate that no interference of excipients in the determination of Prothionamide by the proposed method. The standard deviation, coefficient of variance and standard error were obtained for Prothionamide was significantly low. Result of precision at different levels was found to be within acceptable limits $(\mathrm{RSD}<2)$.

\section{CONCLUSION}

Simple, rapid, accurate and precise UV- spectrophotometric methods have been developed and validated for route analysis of Prothionamide in API and tablet dosage forms. There is no interference of phosphate buffer $\mathrm{pH} 7.4$ solution in the estimation of Prothionamide. This proposed method, thereby decreasing the time and the error in the quantization.

\section{ACKNOWLEDGEMENT}

Authors would like to acknowledge Ms. Deepa Rada (Student, Quality Assurance) for the support.

\section{REFERENCES}

Bartels, H., Bartels, R. (1998). Simple, rapid and sensitive determination of protionamide in human serum by high-performance liquid chromatography. J. Chromato. Biomed. Sci. Appli. 707(1-2): 338-341. [DOI]

Bijev, A., Georgieva, M. (2010). The development of new tuberculostatics addressing the return of tuberculosis: current status and trends. J. Uni. Chem. Tech. Metallurgy. 45(2): 111-126.

Jain, R., Jain, N., Jain, D.K., Patel, V.K., Rajak, H., Jain, S.K. (2013). Novel UV spectrophotometer methods for quantitative estimation of metronidazole and furazolidone using mixed hydrotropy solubilization. Arb. J. Chem. 1-6. [DOI]

Kavathia, A. Misra, M. (2013). Development and validation of RP-HPLC and UV-spectrophotometric methods for rapid simultaneous estimation of amlodipine and benazepril in pure and fixed dose combination. Arb. J. Chem. 1-8. [DOI]

Kumar, M.P., Sreeramulu, J. (2011). Development and validation of a stability-indicating Reverse-phase high performance liquid chromatography method for assay of prothionamide in pure and pharmaceutical dosage form. Int. J. Chamtech. Res., 3(1): 321-328.

Lee, J.K., Cho, W.H., Bae, J.W., Kim, Y.U., Park, G.B., Yuk, S.H., Lee, D.W., Khang, G. (2012). Improvement of Prothionamide Dissolution by Solid Dispersion with Complex Polymer. Int. J. Tis. Rege. 3(1): 28-38.

Minilab, GPHF. (2010). Thin layer chromatographic tests. A Concise Quality Control Guide on Essential Drugs and other Medicines.

Nijhu, R.S., Akhter, D.T., Jhanker Y.M. (2011). Development and validation of UV spectrophotometric method for quantitative estimation of nitroglycerin in pharmaceutical dosage form. Int. Curr. Pharma. J. 1(1): 1-5. [DOI]

Prothionamide, Indian Pharmacopoeia, (2007). 3rd volume, The Indian Pharmacopoeia Commission Ghaziabad, 1002-1005.

Prothionamide, Japan Pharmacopoeia, 14th edition, (2011): 720

Venkatesan, K. (1989). Clinical Pharmacokinetic considerations in the treatment of patients with leprosy. Clini. Pharmaco; 16: 365-386. [DOI] 